\title{
Analisa Dan Perancangan Pelaporan Hasil Kerja Dengan Reminder Sistem (Studi Kasus PT Indosat)
}

\author{
Putri Kusriyanti ${ }^{[1]}$, Tarimantan Sanberto Saragih, ST,MISM ${ }^{[2]}$ \\ Fakultas Ilmu Komputer, Universitas Mercu Buana ${ }^{[1]}$, Fakultas Ilmu Komputer, Universitas Mercu Buana ${ }^{[2]}$ \\ Jakarta, Indonesia \\ 41815110138@student.mercubuana.ac.id ${ }^{[1],}$ tarimantan.saragih@mercubuana.ac.id ${ }^{[2]}$
}

\begin{abstract}
Abstrak - Pelaporan adalah salah satu fungsi manajemen berupa penyampaian perkembangan atau hasil kegiatan atau pemberian keterangan mengenai segala hal yang bertalian dengan tugas dan fungsi-fungsi kepada pejabat yang lebih tinggi. Permasalahan yang ada pada tim RAN (Radio Access Network) di Indosat Ooredoo ini adalah pelaporan yang belum terpusat dalam satu sistem sehingga seringkali mengalami keterlambatan dalam penyajian informasi yang berkaitan dengan pelaporan hasil kerja karyawan. Oleh sebab itu peneliti mencoba melakukan analisa pada bisnis proses berjalan di tim RAN untuk menemukan pokok permasalahan dan melakukan perancangan sistem informasi pengolahan data pelaporan hasil kerja, dengan tujuan efisiensi biaya dan waktu dapat dicapai. Adapun hasil yang ingin didapat dari perancangan sistem usulan ini adalah agar mempermudah dalam pengolahan data pelaporan, pembuatan weekly report, pencarian data hasil eksekusi, serta pemberian reminder berupa notifikasi yang diterima lewat email oleh karyawan yang sedang melakukan eksekusi data proyek. Metode yang digunakan pada pengolahan data pelaporan ini menggunakan konsep UML, metode System Development Life Cycle (SDLC) model agile dan pengelolaan data dengan MySQL.
\end{abstract}

Kata Kunci - konsep UML, model agile, MySQL, sistem informasi, pelaporan hasil kerja

\section{PENDAHULUAN}

Reporting (pelaporan) menurut Luther M. Gullick dalam bukunya Papers on the Science of Administration merupakan salah satu fungsi manajemen berupa penyampaian perkembangan atau hasil kegiatan atau pemberian keterangan mengenai segala hal yang bertalian dengan tugas dan fungsifungsi kepada pejabat yang lebih tinggi. [1]

PT. Indosat Ooredoo adalah nama dari salah satu perusahaan penyedia jasa telekomunikasi dan jaringan telekomunikasi di Indonesia, perusahaan ini menawarkan saluran komunikasi untuk pengguna telepon genggam dengan merek jual Martix, Mentari dam IM3. Jasa lainnya yang disediakan adalah saluran telekomunikasi via suara untuk telepon tetap termasuk sambungan langsung internasional, serta jasa nirkabel dengan merek dagang StarOne. Perusahaan ini juga menyediakan layanan multimedia, internet dan komunikasi data MIDI (Multimedia, Internet \& Data Communication Service). PT Indosat Ooredoo sebagai salah satu perusahaan telekomunikasi di Indonesia dengan lebih dari 150 juta pelanggan yang memungkinkan setiap harinya mengakses informasi, berkomunikasi dan berinternet secara bebas. [2] Tiga vendor yang bekerja sama dengan PT. Indosat adalah Nokia, Huawei, dan Ericsson.

Untuk mendukung dan menjaga operasional perusahaan peran teknologi informasi sangat diperlukan. Utamanya suatu sistem yang mampu melakukan pengolahan data secara cepat, akurat, serta informasi yang dihasilkan tersimpan dam terpusat dalam satu database. Sama halnya dengan di tim Radio Access Network (RAN) PT Indosat, membutuhkan penerapan teknologi informasi dalam pengelolan dan pengolahan data yang berkaitan dengan hasil eksekusi tim RAN yaitu berupa sistem informasi pelaporan hasil kerja karyawan. Sistem ini diperlukan karna pada bisnis proses berjalan saat ini pada pelaporan hasil kerja karyawan yang berupa hasil eksekusi data proyek masih direkap secara manual dengan bantuan aplikasi Microsoft Excel. Dengan penggunakan aplikasi Microsoft Excel tersebut penyimpanan data tidak terorganisir dengan baik, sering terjadi perbedaan jumlah data proyek yang direkap dengan data proyek yang di-request sebelum proses eksekusi dilakukan. Terlebih saat akan dibuat weekly report harus dilakukan compile antara data proyek yang direkap dengan yang di-request sehingga memakan waktu yang lama. Selain itu, tidak adanya reminder sistem yang ditujukan pada tim eksekutor mengakibatkan proses pelaporan hasil eksekusi data proyek menjadi tidak tepat waktu, sehingga data proyek yang direkap menjadi tidak up-to-date dan seringkali mengalami perbedaan jumlah.

Berikut ini adalah chart pie yang beriisikan data kepuasan pelanggan terkait proses bisnis yang berjalan saat ini

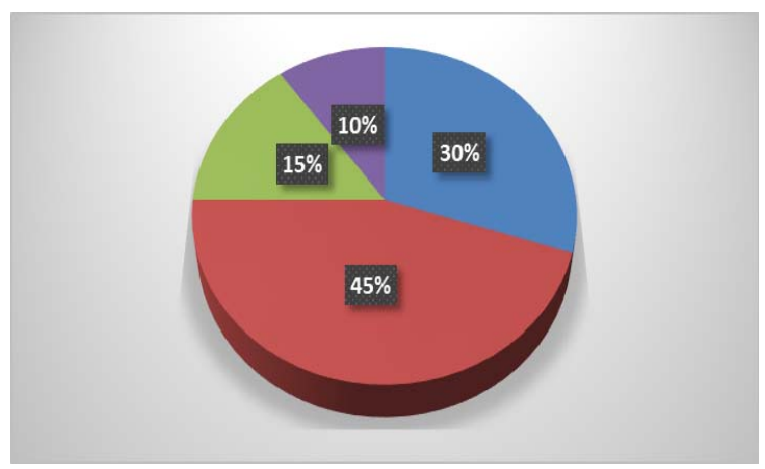

Gambar 1. Data Kepuasan Pelanggan

ISSN : 2301-7988

E-ISSN : 2581-0588

DOI : $10.32736 /$ sisfokom.v8i2.639 
Data diatas diperoleh dari proses penyebaran kuisioner yang dilakukan peneliti kepada 20 responden yang merupakan karyawan di tim RAN divisi Configuration Management. Dan 20 responden yang mengisi kuisioner terdiri dari 5 karyawan wanita dan 15 karyawan laki-laki diluar manager (di khususkan hanya untuk karyawan yang pekerjaannya berkaitan dengan bisnis proses berjalan) yang dapat mengisi kuisioner tingkat kepuasan karyawan ini.

Dan hasil dari kuisioner yang diberikan, terdapat sebanyak 9 karyawan merasa perlu adanya perbaikan pada proses berjalan saat ini. 6 karyawan merasa tidak perlu adanya perbaikan dari proses bisnis berjalan saat ini. 3 karyawan merasa ragu-ragu untuk memilih antara perlu perbaikan atau tidak pada proses bisnis berjalan saat ini karena pekerjaan yang mereka kerjakan sudah berjalan dengan semestinya. Terakhir sebanyak 2 karyawan menjawab tidak tahu atas permasalahan yang telah dihadapi pada tim RAN ini.

Sehingga berdasar pada permasalahan yang ada, suatu sistem yang terintegrasi serta terhubung dengan database amat diperlukan untuk mempermudah proses pelaporan hasil eksekusi data proyek dan pengolahan data pelaporan untuk weekly report. Agar masalah yang ditimbulkan oleh implementasi proses bisnis berjalan saat ini bisa teratasi dan tertangani dengan tepat, mudah serta tidak memakan waktu yang lama karena data telah terintegrasi dalam satu database. Database adalah kumpulan data atau informasi yang disimpan dalam computer. Adapun fungsi database adalah sebagai penyimpan data, pusat pencarian data, pengelompokkan data dan memudahkan user dalam mengelola data dan menjadikan lebih efektif [3]. Saat karyawan ingin memperoleh informasi yang berkaitan dengan data pelaporan hasil eksekusi data proyek, dapat dilakukan secara mudah, akurat dan sesuai dengan kebutuhan. Informasi merupakan data yang telah berhasil dilakukan klasifikasi atau diinterpretasi yang digunakan dalam proses pengambilan keputusan [4]. Sistem informasi dapat dianalogikan sebagai sebuah permintaan (demand) dari masyarakat industry, ketika kebutuhan akan sarana pengolahan data dan komunikasi yang cepat dan murah (menembus ruang dan waktu) [5]. Sistem informasi merupakan sekelompok elemen yang saling berhubungan atau berinteraksi hingga membentuk kesatuan [6].

Penelitian sebelumnya berjudul Desain and Implementation of Treasury Application Based on Mobile in Student Organization Mercu Buana University menjadi salah satu rujukan untuk melakukan penelitian pelaporan hasil kerja ini. Dalam jurnal penelitian yang diterbitkan ditahun 2018 tersebut membahas tentang proses pencatatan keuangan yang masih dilakukan dengan cara manual, yaitu dengan ditulis dalam kertas sehingga rawan terselip, dan hilang. Sehingga menyulitkan proses pembuatan laporan hasil pemasukan dan pengeluaran yang dilakukan setiap bulannya. Oleh sebab itu dibangun sebuah aplikasi berbasis android dengan pendekatan prototyping, analisa PIECES dengan desain UML (Unified Modeling Language) serta pengujian black box testing. Dengan aplikasi baru yang dibangun berbasis android diharapkan mampu memanajemen keuangan dengan seksama serta proses pembuatan laporan hasil pemasukan dan pengeluaran dapat dilakukan dengan cepat karna sudah terkomputerisasi dengan baik.[7] Terdapat perbedaan antara pendekatan model yang digunakan dalam penelitian ini dengan penelitian sebelumnya, pada penelitian sebelumnya digunakan pendekatan model prototyping dengan mendengarkan keluhan user, dilanjutkan dengan perancangan sistem dan terakhir dengan pengujian sistem.Penelitian ini dijadikan rujukan karena untuk mengetahui metode pengembangan mana yang lebih sesuai untuk perancangan sistem informasi pelaporan hasil eksekusi data proyek antara pendekatan prototyping, waterfall dan Agile. Model yang digunakan untuk mendesain sistem pada penelitian ini adalah dengan menggunakan model agile. Model agile dipilih peneliti sebagai metode pengembangan pada pelaporan hasil eksekusi data proyek didasari oleh hasil wawancara yang menurut narasumber kebutuhan sistem dapat berubah sewaktu-waktu, sehingga besar kemungkinan diperlukan pengembangan bertahap dan berulang pada satuan waktu yang kecil [8].

Penelitian sebelumnya berjudul Pengembangan Aplikasi Sistem Informasi Laporan Keuangan Walisantri di Pondok Pesantren Al-Halim Garut juga menjadi rujukan dalam melakukan penelitian pelaporan hasil kerja. Dalam jurnal penelitian yang diterbitkan tahun 2015 tersebut membahas tentang dibutuhkannya sistem komputerisasi yang komplek dibidang administrasi yang mampu mempermudah pekerjaan walisantri dalam membuat laporan keuangan pesantren. Selama ini proses pembayaran dilakukan dengan menyimpan data pembayaran dengan arsip buku. Hal ini tentu menyulitkan proses pembuatan laporan keuangan pesantren. Pendekatan model yang digunakan pada penelitian sebelumnya adalah model RAD (Rapid Application Development) yang dimulai dengan fase perencanaan kebutuhan, desain tampilan, dan implementasi. Dengan penerapan sistem yang baru proses penyimpanan data menjadi terpusat sehingga memudahkan proses pengolahan dan pencarian data [9]. Berdasarkan jurnal yang diterbitkan tersebut, menjadi rujukan dalam melakukan penelitian pelaporan hasil kerja untuk mendesain sistem untuk mengetahui seberapa efisien metode pengembangan RAD dibanding Agile dalam mendukung pengembangan sistem informasi yang telah dirancangan dan akan mengalami perubahan sewaktu-waktu.

Penelitian sebelumnya berjudul Web-Based Application For Tracking, Listing and Reporting Dokumen Review (Case Study : PT. XYZ) [10]. Dalam penelitian yang diterbitkan pada tahun 2018 ini permasalahan yang ditemukan hampir mempunyai kemiripan yaitu seputar pelaporan dokumen internal perusahaan. Hanya saja metode pengembangannya menggunakan waterfall dan peneliti memilih menggunakan agile karena disesuaikan dengan perubahan kebutuhan sistem yang dapat berubah sewaktu-waktu pada operasional perusahaan. Jurnal ini dijadikan rujukan karna penggunakan database MySQL sebagai media penyimpanan data.

Perbedaan dalam penelitian ini berdasarkan penelitian terdahulu adalah pada analisa dan perancangan ini disertai reminder sistem berupa notifikasi atau pengingat kepada tim eksekustor RAN agar selalu melakukan update progress kerja atau unggah report hasil eksekusi data proyek.. Reminder sistem akan diterima oleh karyawan yang usernya telah

ISSN : 2301-7988

E-ISSN : 2581-0588

DOI : $10.32736 /$ sisfokom.v8i2.639 
terdaftar dalam sistem setiap 3 jam sekali. Notifikasi ini akan memudahkan untuk memberikan informasi kepada karyawan saat ada request data proyek yang telah diinput dalam sistem. Selanjutnya bila ada request dan nama eksekutor telah ditetapkan maka user (yang menjadi eksekutor data proyek) akan mendapat notifikasi setiap 45 menit yang berisikan peringatan untuk mengunggah laporan hasil eksekusinya ke dalam sistem.

\section{METODOLOGI PENELITIAN}

Metodologi yang digunakan pada penelitian pelaporan ini adalah menggunakan metode Agile. Model agile pertama kali dipublikasikan pada tahun 1999 dengan pendekatan OOP (Objek Oriented Programming). Model SDLC agile adalah kombinasi dari model proses yang berulang dan incremental dengan fokus pada proses adaptasi kepuasan pelanggan. pendekatan secara sistematis dan berurutan mulai dari level perencanaan, desain, coding dan testing [11]. Metode pengembangan ini bersifat daur hidup sebab setelah selesai tahap implementasi juga pemeliharaan maka sistem akan memberikan umpan balik ke analisis yang dirancang, sehingga tahapan tersebut terus-menerus dilakukan guna penyempurnaan sistem [12].

Untuk metode analisis dan perancangan sistem informasi yang akan dibangun digunakan pemodelan berorientasi objek dengan menggunakan alat bantu UML (Unified Modeling Languange) yang mempunyai pengertian merupakan bahasa standar yang digunakan dalam industri sebagai visualisasi, merancang dan mendokumentasikan sistem perangkat lunak [13].

Adapun metode penelitian yang harus diterapkan untuk memecahkan masalah dalam melakukan analisa adalah sebagai berikut :

A. Observasi

Pengumpulan data yang dilakukan dengan metode pengamatan pada sistem berjalan untuk mengetahui proses yang terjadi dalam pelaporan hasil kerja karyawan di RAN (Radio Access Network) tim. Tujuan dilakukannya observasi ini adalah untuk memahami kendala-kendala yang dialami oleh team selama proses pelaporan hasil kerja sampai dengan proses pembuatan weekly report yang akan dikirimkan manager, sehingga diharapkan mampu ditemukan titik lemahnya dari sistem berjalan yang selama ini diterapkan dan rutin dilakuan.

\section{B. Studi Pustaka}

Pengumpulan data yang dilakukan dengan mengumpulkan teori-teori yang bersumber dari buku-buku serta jurnaljurnal yang dapat mendukung penelitian ini.

\section{Wawancara}

Untuk mendapat informasi secara lengkap maka penulis melakukan metode tanya jawab langsung kepada beberapa staff yang berkaitan dengan pekerjaan di tim RAN guna mengetahui alur proses bisnis pelaporan hasil kerja karyawan yang diterapkan selama ini. Selain itu dilakukan penyebaran kuisioner yang diisi oleh 20 karyawan di tim
RAN berkaitan dengan kepuasan karyawan atas proses bisnis yang berjalan saat ini.

\section{Tahap Perencanaan}

Pada langkah ini pengembang aplikasi dan klien saling berkomunikasi untuk membuat rencana dan rancangan tentang kebutuhan dari perangkat lunak yang akan dibangun. Perancangan sistem bertujuan untuk menganalisa kebutuhan sistem yang akan diusulkan. Percangan sistem memuat tiga kebutuhan sistem yang harus dipenuhi, yang pertama adalah Software Architecture yang meliputi usecase diagram, sequence diagram, dan class diagram. Kedua adalah perancangan basis data dengan menggunakan Entity Relationship Diagram. Yang ketiga perancangan interface atau perancangan tatap muka yang akan memberikan gambaran tampilan dari sistem yang diusulkan dengan tujuan mempermudah dalam pengoperasian sistem.

\section{E. Tahap Implementasi}

Tahap implementasi adalah tahap dimana programmer melakukan pengkodean perangkat lunak. Pengkodean bertujuan untuk menerjemahkan bahasa manusia ke dalam bahasa mesin (bahasa komputer).

\section{F. Tahap Tes perangkat lunak (Testing)}

Perangkat lunak yang telah berhasil dibuat akan dilakukan pengetesan perangkat oleh bagian control kualitas (tester) agar buglerror yang ditemukan bisa segera diperbaiki dan kualitas perangkat lunak terjaga.

\section{G. Tahap Dokumentasi}

Setelah dilakukan testing, langkah selanjutnya yang harus dilakukan yaitu proses dokumentasi perangkat lunak yang bertujuan untuk mempermudah proses maintenance kedepannya.

\section{H. Tahap Deployment}

Tahap ini dilakukan untuk menjamin kualitas sistem yang telah berhasil dirancang. Setelah sistem memenuhi syarat maka perangakat lunak siap di deployment.

\section{Tahap Pemeliharaan}

Tahap pemeliharaan ini harus dilakukan berkala guna memastikan sistem berjalan sesuai dengan kebutuhan. Tidak ada perangkat lunak yang $100 \%$ bebas dari bug jadi rutinitas pemeliharaan harus rutin dijalankan.

\section{HASIL DAN PEMBAHASAN}

Guna mendapatkan data yang berhubungan dengan sistem informasi pelaporan hasil kerja dari eksekusi data proyek, maka dilakukan proses wawancara dengan beberapa narasumber yang berkaitan erat dengan pekerjaan di tim RAN dan memahami alur bisnis proses yang berjalan saat ini. Di tim RAN wawancara dilakukan dengan SPV RAN, sebab SPV RAN sering ditunjuk sebagai kordinator penangungjawab atas data proyek yang dikirimkan oleh requestor. Selain SPV,

ISSN $: 2301-7988$

E-ISSN : 2581-0588

DOI : $10.32736 /$ sisfokom.v8i2.639 
wawancara juga dilakukan dengan staff di tim planning yang bertugas melakukan pengajuan nota dinas. Kemudian juga dilakukan wawancara dengan salah satu staff dari tim NPO yang bertugas me-request eksekusi data proyek ke tim RAN. Dan berdasarkan hasil wawancara yang telah dilakukan mengenai proses bisnis berjalan maka dapat dilihat pada activity diagram dibawah ini:

\section{A. Activity Diagram Proses Pengajuan Nota Dinas}

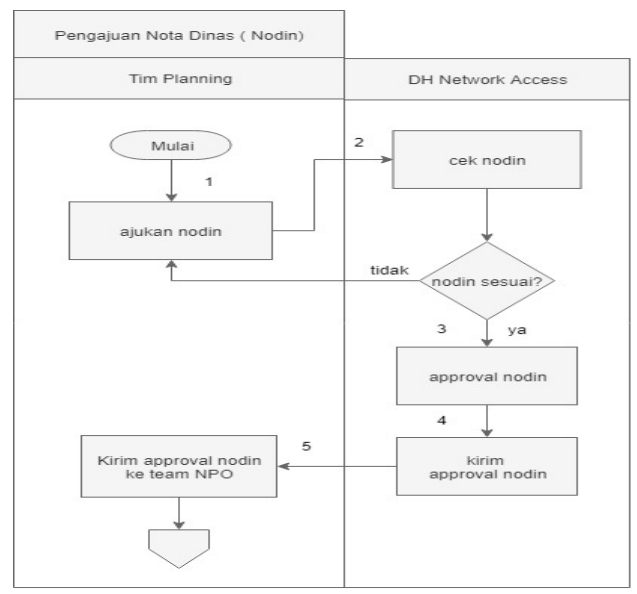

Gambar 2. Activity Diagram Pengajuan Nota Dinas

Gambar 2: Menjelaskan proses bisnis pengajuan nota dinas (nodin) yang dilakukan oleh tim planning ke Division Head Network Access. Tahapan ini dimulai dengan tim planning mengajukan nodin yang kemudian dicek kelengkapan data nodin oleh Division Head Network Access. Bila kelengkapan nodin sudah lengkap dan sesuai maka nodin akan disetujui dan dikirimkan ke tim NPO (Network Project Optimization) untuk dilakukan tahap selanjutnya, namun bila nodin yang diajukan tidak sesuai kelengkapan datanya maka dikembalikan ke tim planning.

\section{B. Activity Diagram Proses Pengajuan Data Proyek}

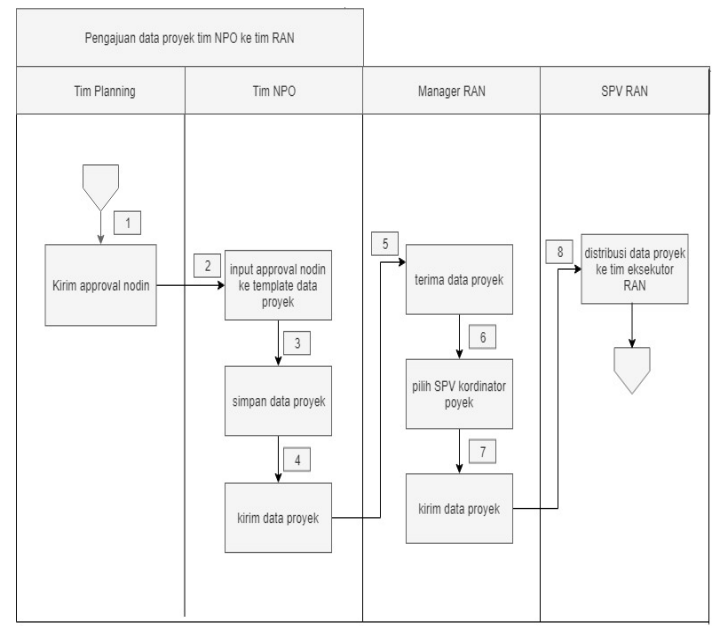

Gambar 3. Activity Diagram Pengajuan Data Proyek
Gambar 3: Menjelaskan proses bisnis pengajuan data proyek yang berasal dari nodin yang dikirim oleh tim planning. Setelah tim planning mengirimkan nodin ke tim NPO, tahapan yang dilakukan tim NPO adalah menginput data yang ada dalam nodin ke dalam template data proyek yang kemudian disimpan dan dikirimkan ke tim RAN (Radio Access Network) melalui manager RAN. Selanjutnya manager RAN yang menerima data proyek akan memilih satu supervisor sebagai kordinator proyek.

\section{Activity Diagram Proses Eksekusi Data Proyek}

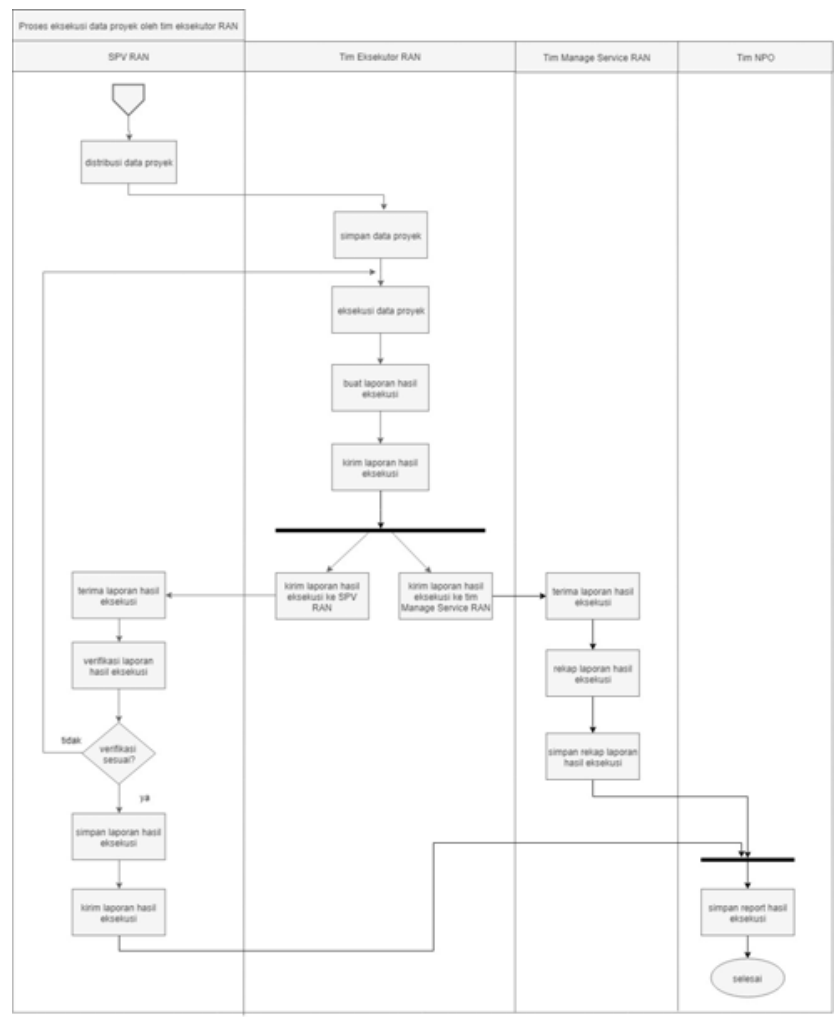

Gambar 4. Activity Diagram Eksekusi Data Proyek

Gambar 4: Menjelaskan proses bisnis eksekusi data proyek yang dimulai dari SPV mendistribusikan data proyek ke tim eksekutor sesuai dengan vendor yang ditangani. Selanjutnya tim eksekutor melakukan eksekusi data proyek lalu membuat laporan hasil eksekusi data proyek dan mengirimkan laporan hasil eksekusi data proyek ke SPV RAN sebagai pelaporan hasil kerja harian. Selain dikirimkan ke SPV RAN, laporan hasil eksekusi data proyek juga dikirimkan ke tim MS RAN (manage service) untuk dilakukan proses perekapan. Laporan hasil eksekusi data proyek yang diterima oleh SPV RAN akan dilakukan verifikasi untuk mengecek apakah eksekusi data proyek benar dilakukan oleh tim eksekutor atau tidak. Bila hasil verifikasi sesuai maka laporan hasil eksekusi data proyek tersebut akan dikirimkan ke tim NPO sebagai bentuk pelaporan hasil eksekusi data proyek atas pengajuan eksekusi

ISSN : 2301-7988

E-ISSN : 2581-0588

DOI : $10.32736 /$ sisfokom.v8i2.639 
data proyek dikirimkan sebelumnya.

Selain dilakukan wawancara untuk memperoleh data yang berhubungan dengan sistem pelaporan hasil kerja yang sedang diteliti, juga dilakukan identifikasi masalah dengan menggunakan tahap analisis PIECES (Peformance, Information, Economy, Control, Efficiency, Service)

\section{a) Performace}

Proses sistem berjalan : SPV RAN tidak dapat membuat weekly report secara langsung berdasarkan hasil rekap data dari tim MS RAN (manage service). Laporan progress hasil eksekusi data proyek tidak bisa di-update sewaktu-waktu.

Sistem Usulan : Terdapat fitur untuk meng-export laporan yang telah dipisah dalam beberapa kategori sehingga memudahkan SPV memilih jenis laporan sesuai kebutuhan. Terdapat fitur yang memudahkan user untuk melakukan update laporan hasil eksekusi setiap saat.

\section{b) Information}

Proses sistem berjalan : Data pelaporan hasil kerja karyawan tidak terorganisasikan dengan baik, sering terjadi salah input data dan input jumlah.

Sistem Usulan : Terdapat fitur yang mampu mengelola informasi dan data pelaporan hasil kerja karyawan sesuai dengan fungsinya.

\section{c) Economy}

Proses sistem berjalan : Tim eksekutor sering lupa menginfokan hasil kinerja mereka, sehingga harus dihubungi melalui telefon.

Sistem Usulan : Terdapat fitur reminder sistem berupa notifikasi yang dikirim per satu jam ke email seluruh tim sehingga membantu tim untuk menginfokan hasil kinerjanya.

\section{d) Control}

Proses sistem berjalan : Proses perekapan laporan hasil eksekusi data proyek belum tercontrol dengan baik.

Sistem Usulan : Terdapat fitur reminder dalam bentuk notifikasi dan fitur update sehingga user dimudahkan dalam melakukan update status data proyek yang sedang dieksekusi.

\section{e) Efficiency}

Proses sistem berjalan : Waktu dan biaya yang dikeluarkan lebih banyak

Sistem Usulan : Waktu dan biaya yang dikeluarkan menjadi lebih sedikit.

\section{f) Service}

Proses sistem berjalan : Manager sering kesulitan dalam memonitoring kinerja tim RAN. Tim NPO kesulitan mengetahui status data proyek yang telah di-request-kan.

Sistem Usulan : Terdapat fitur "View Report" yang memudahkan Manager memonitoring kinerja tim RAN. Terdapat kolom PIC, sehingga memudahkan tim NPO untuk berkoordinasi dengan PIC terkait data proyek yang di-requestkan
Berdasar pada hasil analisa sistem berjalan yang dilakukan diperoleh kebutuhan sistem usulan yang penggambarannya sebagai berikut:

Use case merupakan diagram yang bersifat statis. Diagram ini memperlihatkan himpunan use case dan aktor-aktor (suatu jenis khusus dari kelas). Diagram ini terutama sangat penting untuk mengorganisasi dan memodelkan perilaku dari suatu sistem yang dibutuhkan serta diharapkan pengguna [13].

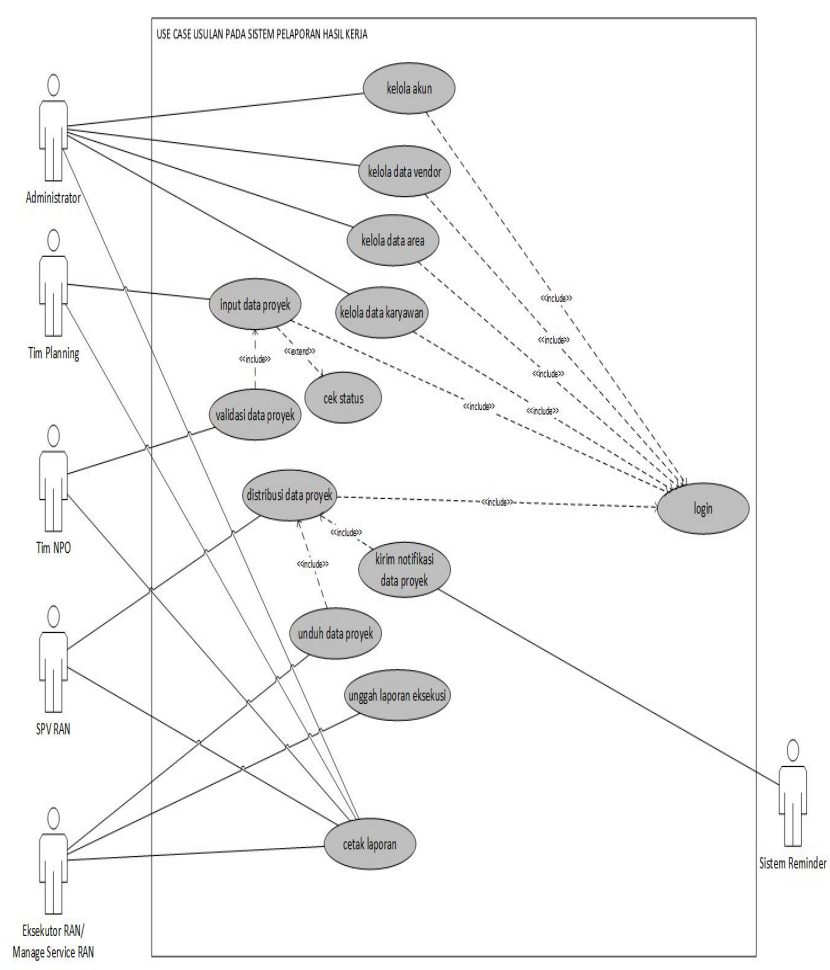

Gambar 5.Use Case Diagram Usulan

Use case diagram usulan menggambarkan penggunaan sistem oleh aktor dengan penjebaran sebagai berikut:

\section{a) Administrator}

Tugas utama dari Administrator adalah melakukan pengelolaan terhadap keseluruhan data yang pada Sistem Pelaporan Hasil Kerja termasuk dalam melakukan penginputan vendor baru, area baru dan karyawan baru yang dapat mengakses sistem.

b) Tim Planning

Memiliki peran dalam melakukan penginputan pekerjaan data proyek yang akan dieksekusi oleh tim RAN.

\section{c) Tim NPO}

Memiliki peran dalam melakukan verifikasi terhadap data proyek yang telah diinput oleh tim planning, bila data proyek telah selesai di verifikasi maka kordinator atau PIC dari tim NPO harus ditetapkan untuk memudahkan proses koordinasi

ISSN : :2301-7988

E-ISSN : 2581-0588

DOI : $10.32736 /$ sisfokom.v8i2.639 
dengan PIC eksekutor dari tim RAN.

\section{d) SPV RAN}

Peran SPV RAN adalah sebagai penanggungjawab atas data proyek yang direquest oleh tim planning, selain itu SPV RAN juga berperan dalam pendistribusian pekerjaan kepada tim eksekutor RAN dan tim manage service RAN.

\section{e) Tim eksekutor dan Manage Service RAN}

Memiliki tugas dalam melakukan eksekusi request pekerjaan data proyek yang telah diinputkan oleh tim planning, selain itu tim eksekutor dan manage service juga membuat laporan hasil eksekusi dari data proyek yang telah berhasil dieksekusi.

\section{f) Sistem Reminder.}

Memiliki tugas untuk melakukan pengiriman notifikasi kepada semua user yang telah terdaftar dalam sistem terkait request data proyek yang telah diinputkan dalam sistem. Notifikasi rutin dikirim ke email user per 3 jam.

Activity diagram bersifat dinamis. Diagram ini adalah tipe khusus dari diagram state yang memperlihatkan aliran dari suatu sistem. Diagram itu terutama penting dalam pemodelan fungsi-fungsi dalam suatu sistem dan memberi tekanan pada aliran kendali antar objek. Activity diagram memodelkan alur kerja (workflow) sebuah proses bisnis dan urutan aktivitas dalam suatu proses. Diagram ini sangat mirip dengan flowchart karena dapat memodelkan sebuah alur kerja dari satu aktivitas ke aktivitas lainnya atau dari satu aktivitas ke dalam keadaan sesaat (state). Activity diagram juga sangat berguna ketika ingin mengambarkan perilaku paralel atau menjelaskan bagaimana perilaku dalam berbagai use case berinteraksi [13].

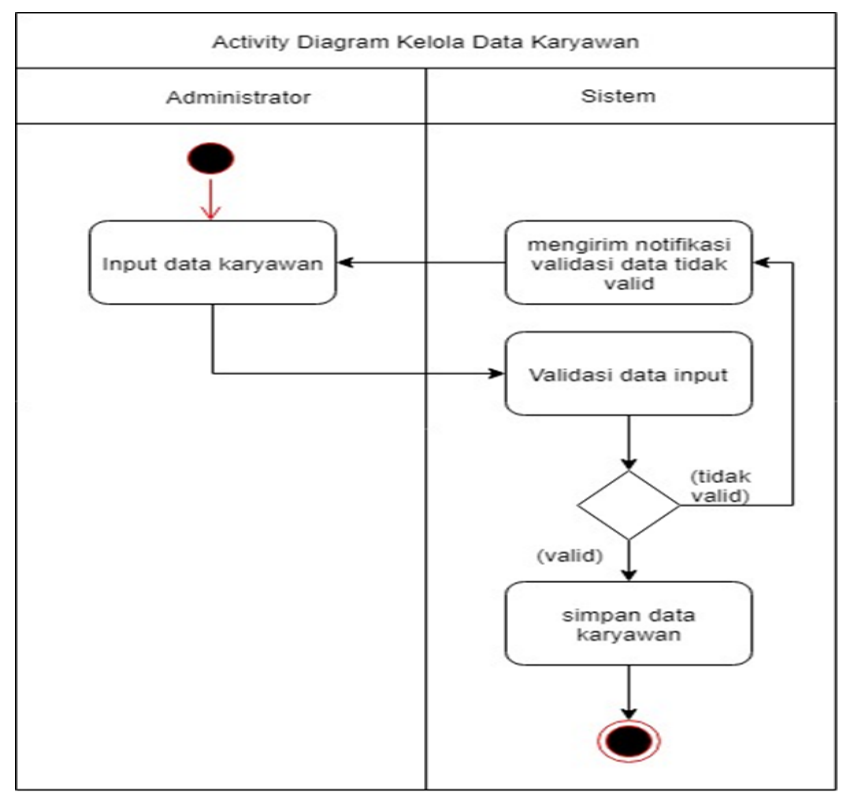

Gambar 6. Activity Diagram Input data karyawan

Gambar 6 : menunjukkan proses dari aktivitas kelola data karyawan untuk melakukan penambahan data karyawan. Pertama administrator akan memasukan data karyawan baru.
Kemudian sistem akan melakukan validasi terhadap data yang telah diinputkan tersebut, bila data yang diinputkan valid dan sesuai maka sistem akan melakukan penyimpanan data. Bila data yang diinputkan tidak valid maka sistem akan menampilkan notifikasi pemberitahuan bahwa data yang diinputkan tidak sesuai dan meminta administrator untuk menginputkan data karyawan kembali.

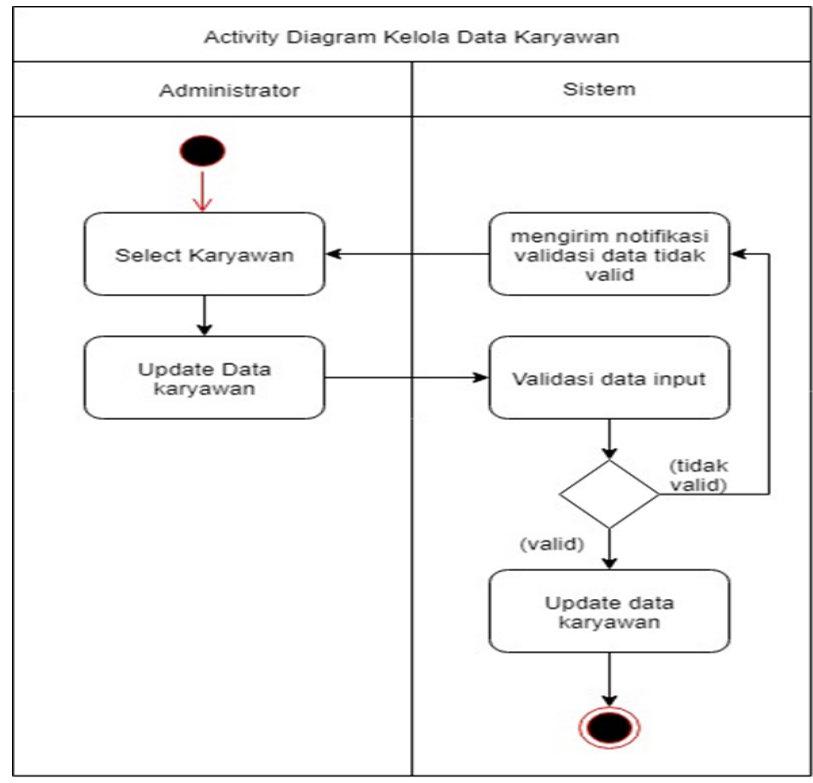

Gambar 7. Activity Diagram Update data karyawan

Gambar 7: menunjukkan proses dari aktivitas kelola data karyawan untuk melakukan pengkinian data karyawan yang telah diinputkan sebelumnya. Pertama administrator akan memilih data karyawan yang akan dilakukan pengkinian data. Kemudian administrator akan memasukan data karyawan baru. Bila data telah selesai diinputkan maka sistem akan melakukan validasi terhadap data yang telah diinputkan tersebut, saat data yang diinputkan sudah valid maka sistem akan menyimpan data perubahan karyawan tersebut. Jika data yang diinputkan tidak valid maka sistem akan menampilkan notifikasi terkait data yang diinputkan tidak sesuai dan meminta administrator untuk menginputkan data karyawan kembali.

Sequence Diagram menjelaskan interaksi antara actor dengan objek atau antar objek yang disusun berdasarkan urutan waktu dan menampilkan pesan yang disampaikan antar objek tersebut. Interaksi ini berupa pengiriman serangkaian data antar objek yang saling berinteraksi [13].

ISSN : 2301-7988

E-ISSN : 2581-0588

DOI : $10.32736 /$ sisfokom.v8i2.639 


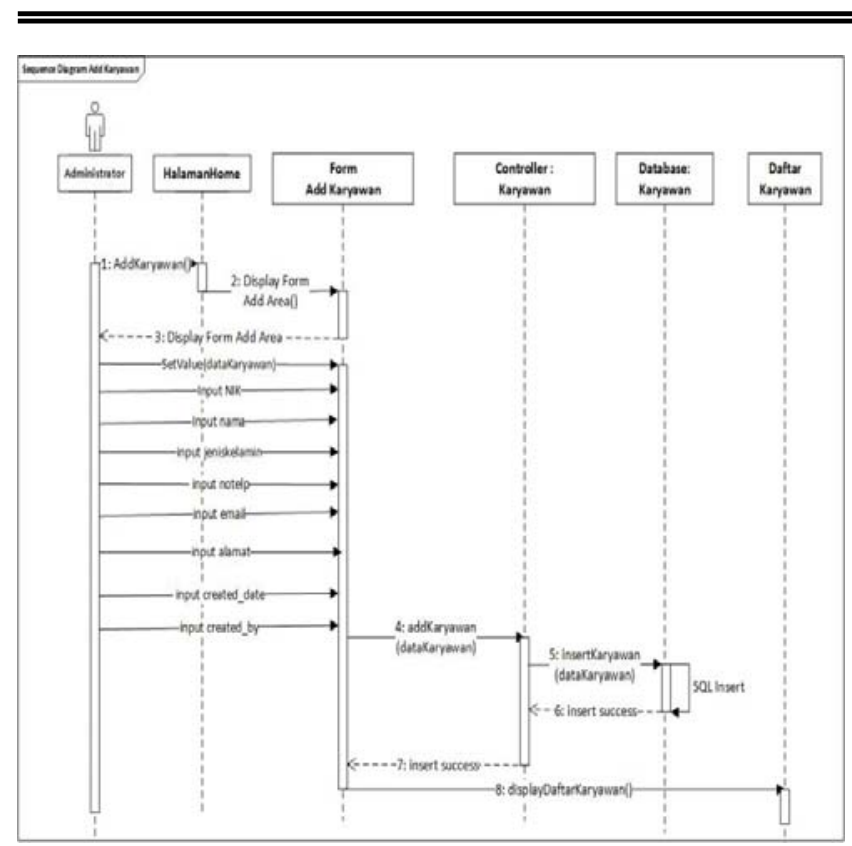

Gambar 8. Sequence Diagram Input data karyawan

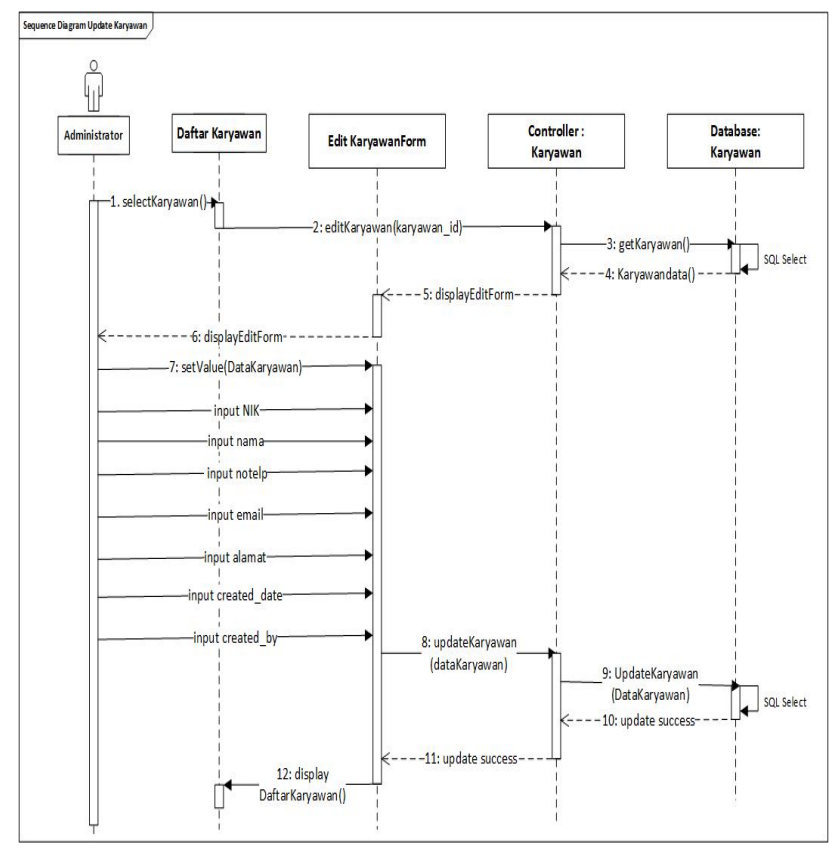

Gambar 9. Sequence Diagram update data karyawan

Setelah proses analisa kebutuhan sistem usulan berhasil dilakukan, tahapan selanjutnya yang dilakukan adalah mendesain perancangan basis data. Berikut adalah hasil perancangan basis data berdasarkan kebutuhan sistem usulan, penjabarannya adalah sebagai berikut:

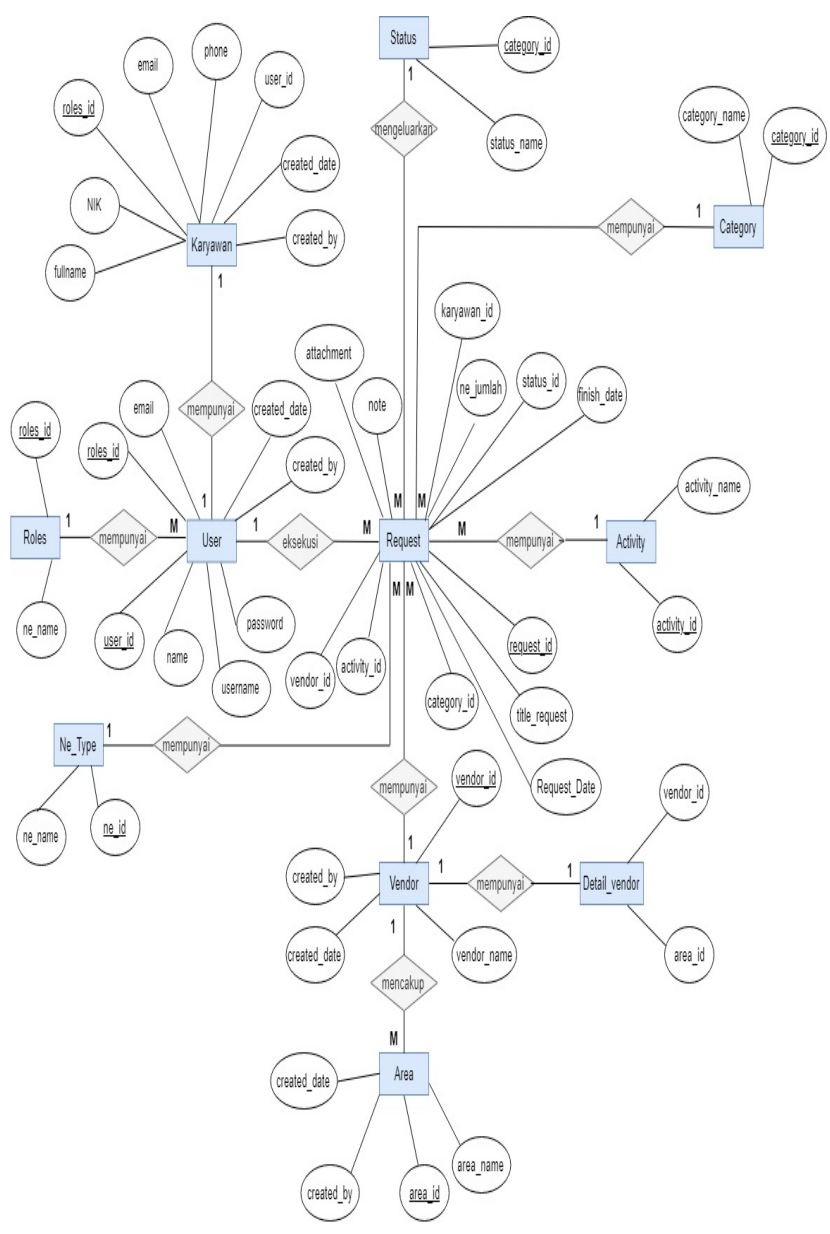

Gambar 10. Entity Relationship Diagram

Gambar 10 : menjelaskan tentang bagaimana hubungan antara entitas satu dengan entitas yang lain berdasar pada analisa dokumen dari sistem berjalan yang selanjutnya dirancang sesuai dengan kebutuhan pada sistem usulan. Adapun data disimpan dalam bentuk relasional maksudnya adalah membawa data kedalam bentuk tabel. Agar tabel yang digunakan untuk menyimpan data terbentuk dengan benar, maka perancangan basis data dengan teknik ERD perlu dilakukan [3].

Berdasar pada perancangan basis data dengan teknik ERD yang telah berhasil dilakukan, selanjutnya dirancang sebuah class diagram. Class diagram menggambarkan struktur dan deskripsi dari class, package, dan objek serta hubungan satu sama lain seperti inheritance, association dan lain-lain. Class diagram nantinya akan berguna sebagai acuan bagi programmer dalam membuat kode program (coding).

ISSN : 2301-7988

E-ISSN : 2581-0588

DOI : $10.32736 /$ sisfokom.v8i2.639 


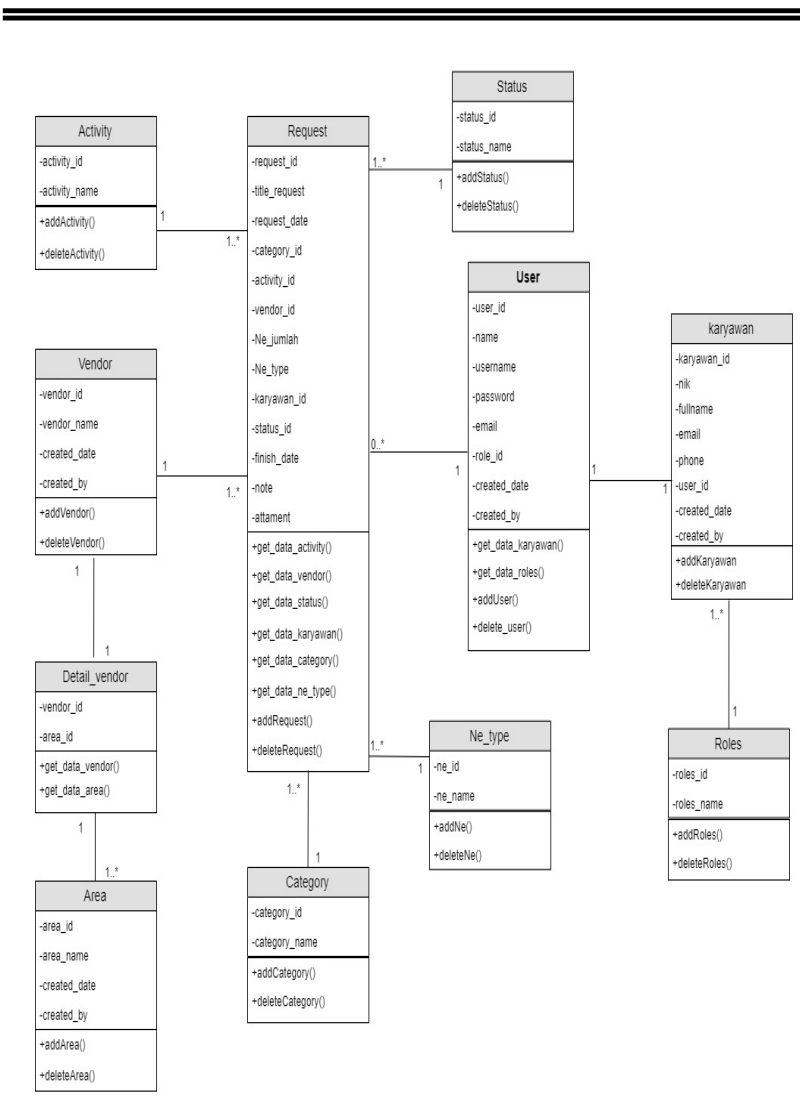

Gambar 11. Class Diagram

Class diagram terdiri dari beberapa tabel master dan tabel transaksi diantaranya adalah sebagai berikut:

1) Tabel Master:

a) Activity : berfungsi untuk menyimpan data tipe aktivitas dari data proyek.

b) Vendor : berfungsi untuk menyimpan data vendor.

c) Area : berfungsi untuk menyimpan data area berdasarkan jenis vendor.

d) Request : berfungsi untuk menyimpan data proyek berdasarkan pada data yang diinputkan.

e) Category : untuk menyimpan data kategori dari masing-masing data proyek.

f) Status : berfungsi untuk menyimpan data status hasil eksekusi data proyek.

g) Karyawan : berfungsi untuk menyimpan data karyawan yang ada.

h) Ne_type : berfungsi untuk menyimpan data tipe Ne dari data proyek.

i) User : berfungsi untuk menyimpan data user yang mengakses sistem.

j) Roles : berfungsi untuk menyimpan data role, role sendiri adalah acuan hak akses untuk user.

2) Tabel transaksi :

a) Detail_vendor : merupakan tabel transaksi yang menghubungkan antara tabel vendor dengan tabel area.
Tahapan selanjutnya yang harus dilakukan setelah perancangan basis data adalah perancangan antar muka. Berikut adalah penjabaran dari perancangan antar muka sistem usulan yang berhasil dibuat :

\section{1) Halaman Kelola Akun}
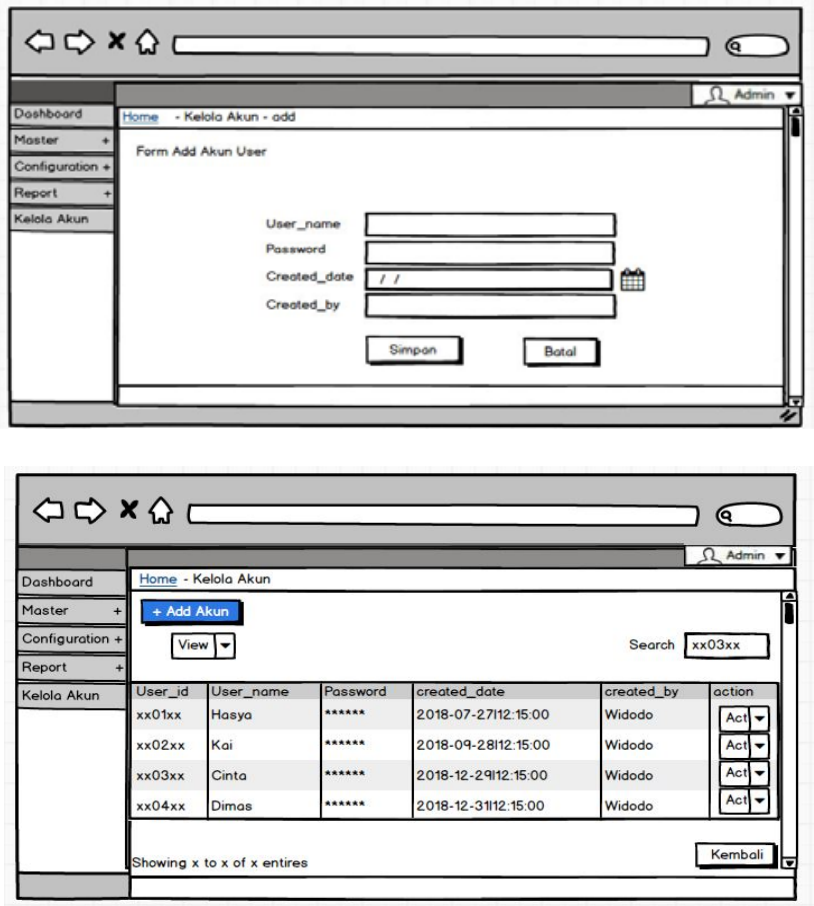

Gambar 12. Halaman Kelola Akun

Halaman kelola akun adalah halam yang berisikan data akun user yang mengakses sistem. Halaman add akun dibuat untuk memudahkan adminstator dalam melakukan pengelolaan data user. Halaman add akun juga hanya dapat diakses oleh administrator.

\section{2) Halaman Kelola Data Vendor}

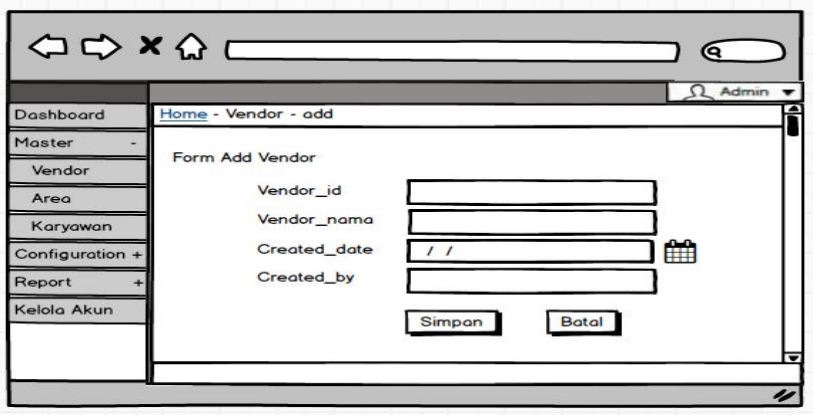




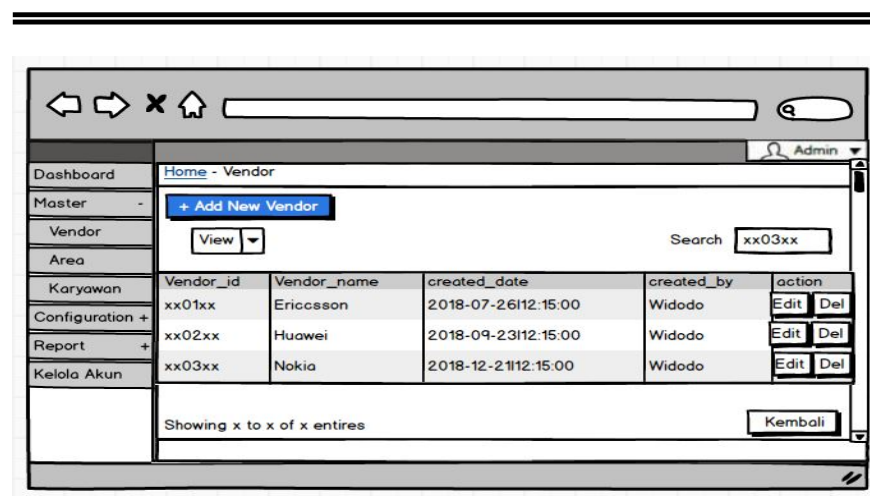

Gambar 13. Halaman Kelola Data Vendor

Halaman kelola data vendor merupakan halaman yang berisikan data vendor yang telah diinputkan dan tersimpan dalam sistem. Halaman add data vendor hanya bisa dilakukan oleh user yang role nya sebagai administrator.

\section{3) Halaman Kelola Data Area}
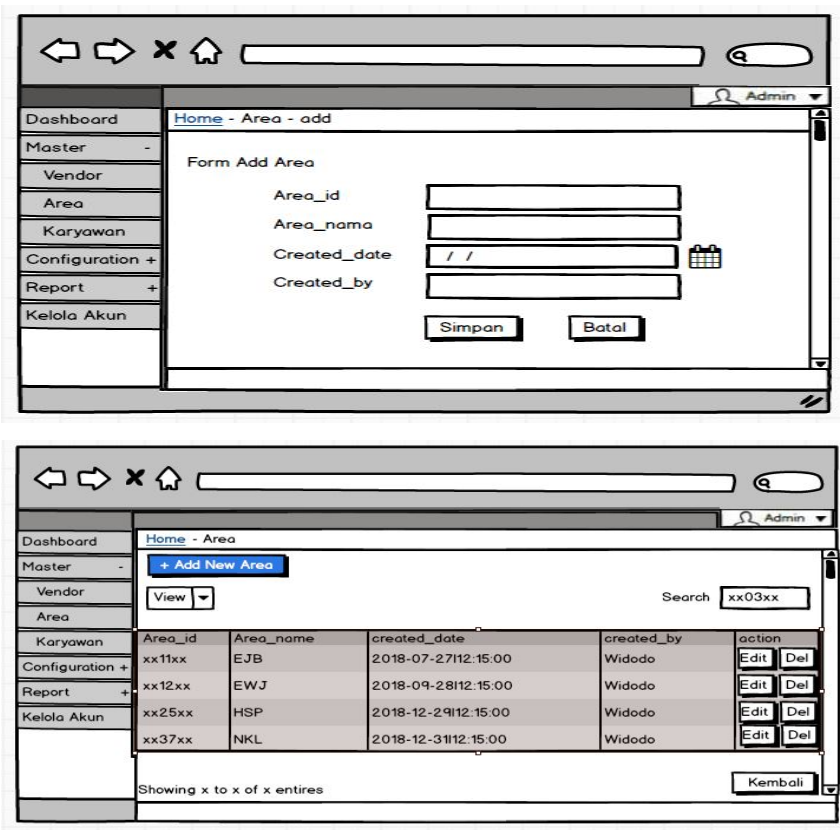

Gambar 14. Halaman Kelola data Area

Halama kelola data area merupakan halaman yang berisikan data area. Halaman add data area bisa diakses oleh user yang role nya berupa administrator. Data area bisa ditambahkan dalam sistem dengan catatan nama vendor sudah terlebih dahulu terinput dalam sistem. Bila nama vendor belum terinput dalam sistem maka data area baru tidak dapat disimpan dalam sistem.

4) Halaman Kelola Data Karyawan
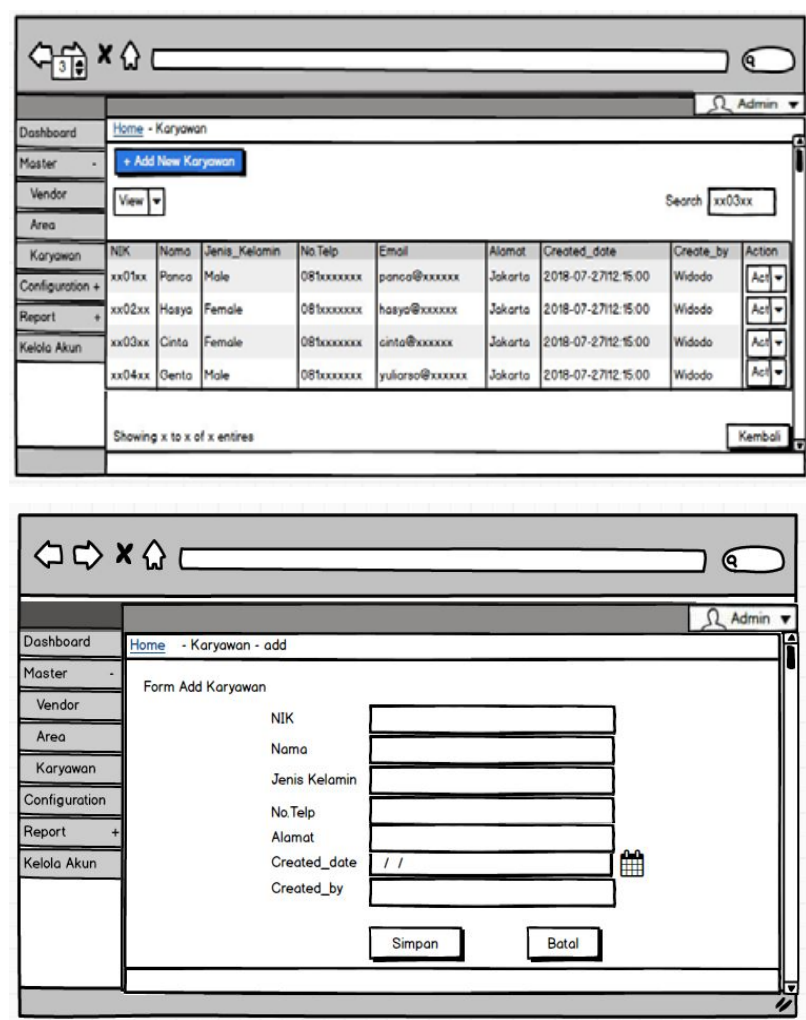

Gambar 15. Halaman Kelola Data Karyawan

Halaman kelola data karyawan adalah halaman yang berisikan data karyawan. Halaman data karyawan ini bisa diakses oleh user yang role nya berupa administrator. Dan halaman add karyawan disediakan untuk menambah data karyawan baru yang hanya bisa dilakukan oleh user dengan role sebagai administrator.

\section{5) Halaman Entry Request}

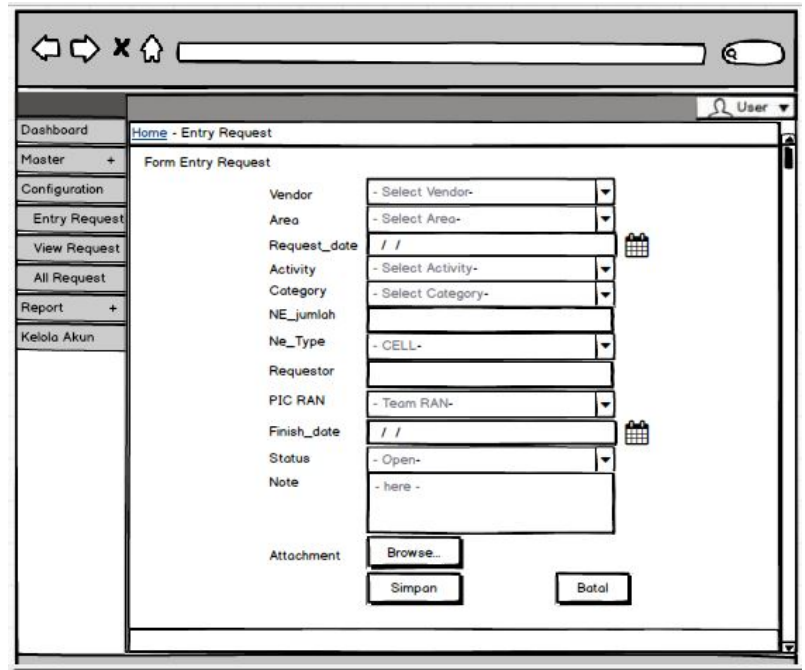

Gambar 16. Halaman Entry Request 
Halaman entry request adalah halaman yang disediakan untuk user melakukan input data proyek yang akan dilakukan eksekusi. Halaman ini bisa diakses oleh user dengan role administrator, maupun user biasa (bukan administrator). Saat data proyek telah terinput semua dan user menekan button simpan maka user akan diberikan nomer tiket atas data proyek yang telah diinputkan. Nomor tiket tersebut nantinya akan memudahkan user dalam melakukan pengecekan data proyek yang diinputkan pada kolom "search" di halaman view request.

Rancangan nomer tiket yang akan didapat requestor hasil dari proses simpan entry request data proyek yang diusulkan adalah sebagai berikut

\begin{tabular}{|l|l|l|l|l|l|l|l|l|l|l|}
\hline $\mathrm{C}$ & $\mathrm{R}$ & 1 & 9 & 0 & 5 & 1 & 1 & 0 & 0 & 1 \\
\hline
\end{tabular}

Keterangan :

a. 2 digit pertama menunjukkan kode transaksi

b. 2 digit kedua menunjukkan kode tahun berlangsungnya transaksi

c. 2 digit ketiga menunjukkan kode bulan berlangsungnya transaksi

d. 2 digit keempat menunjukkan kode vendor dan kode area dari transaksi

e. 3 digit terakhir menunjukkan nomor urutan transaksi

6) Halaman View Request

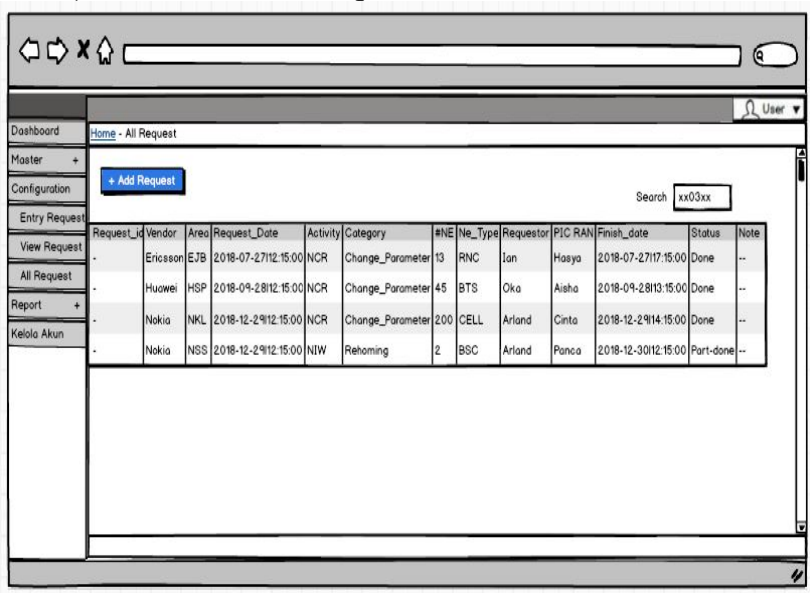

Gambar 17. Halaman View Request

Halaman View Request adalah merupakan halaman yang berisikan data keseluruhan request yang telah diinputkan dalam sistem. User yang mengkases halaman ini akan mendapat informasi terkait kapan tanggal eksekusi data proyek, oleh siapa data proyek dieksekusi dan status terakhir dari data proyek yang telah dieksekusi. Diberikan kolom "search" yang akan memudahkan user yang ingin melakukan pengecekan data proyek berdasarkan nomer tiket yang telah diperoleh sebelumnya pada saat entry request data proyek.

\section{7) Halaman Report}

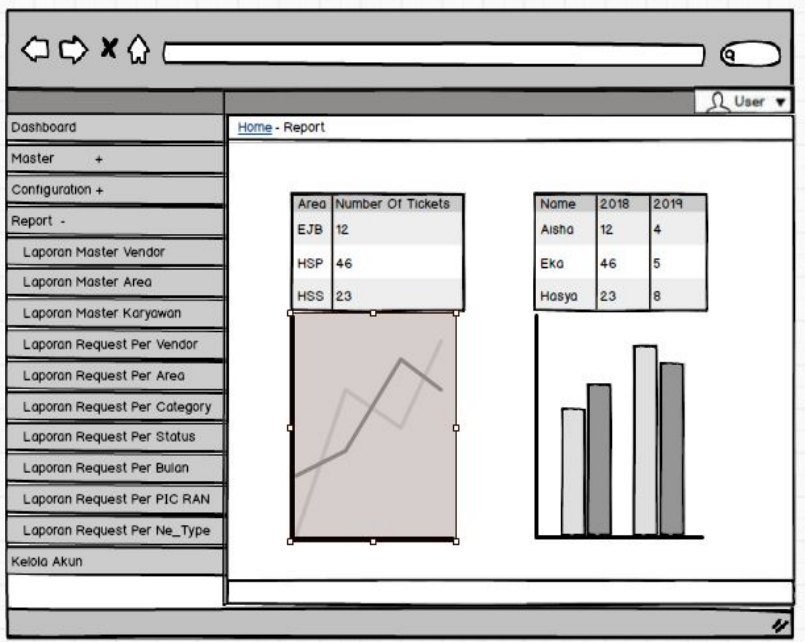

Gambar 18. Halaman Report

Halaman Report adalah halaman yang disediakan untuk memudahkan user melakukan penarikan laporan hasil eksekusi data proyek. Dalam aplikasi ini disediakan fitur laporan yang dipisah kedalam beberapa kategori sehingga memudahkan user dalam memilih laporan sesuai kebutuhan.

Tahapan selanjutnya setelah perancangan antar muka adalah pengujian aplikasi yang telah dibuat, guna memastikan aplikasi sudah berjalan dengan semestinnya dan sesuai dengan kebutuhan user. Dikarenakan pada penelitian ini aplikasi belum dibuat, hanya sebatas analisa dan perancangan maka proses testing atau pengujian perangkat lunak tidak dapat dilakukan.

Berikut ini adalah salah satu contoh keluaran yang dirancangan bila sistem informasi pelaporan hasil kerja karyawan ini benar-benar diimplementasikan.

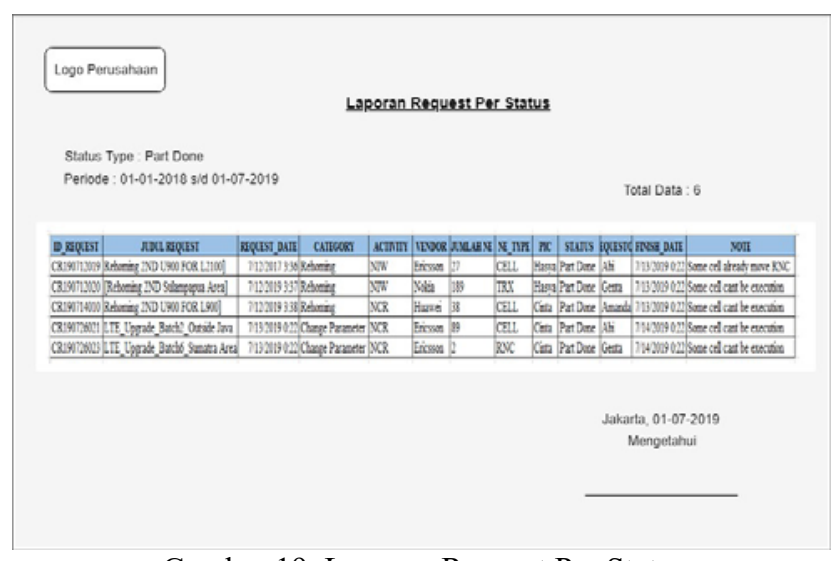

Gambar 19. Laporan Request Per Status

Laporan yang dipisah menjadi beberapa kategori tentunya akan memudahkan SPV RAN dalam melakukan pembuatan 
weekly report yang nantinya akan menjadi acuan manager dalam melakukan pengawasan atas kinerja karyawan di tim RAN.

\section{KESIMPULAN}

Adapun kesimpulan yang dapat diambil dari penelitian pelaporan hasil kerja ini adalah sebagai berikut:

- Sistem informasi pelaporan hasil kerja karyawan pada tim RAN di PT Indosat masih berjalan manual dengan bantuan aplikasi Microsoft Excel. Berdasarkan hasil analisa yang telah dilakukan oleh peneliti sebuah sistem yang terintegrasi dan terpusat dalam satu database dapat dirancang dan kemudian di-deployment untuk mengatasi permasalahan yang ada pada sistem berjalan saat ini. Sehingga sistem informasi pelaporan hasil kerja karyawan yang telah terpusat, memudahkan penyimpanan data yang sebelumnya terekap dalam excel. Dengan penggunaan MySQL sebagai media penyimpanan, data yang ingin dicari dapat dengan mudah ditemukan dan diolah.

- Perancangan sistem informasi pelaporan hasil kerja karyawan ini bila diterapkan pada tim RAN akan dapat membantu SPV RAN dalam melakukan pengelolan dan pengolahan data yang berkaitan dengan pelaporan hasil kerja karyawan yang berupa laporan hasil eksekusi data proyek saat akan membuat weekly report. Semua informasi yang berkaitan dengan data proyek yang direquest dan dieksekusi oleh tim RAN akan terekap dengan baik, dapat diperoleh dengan cepat dan mudah sesuai dengan keinginan.

- Perancangan sistem informasi pelaporan ini dilengkapi dengan fitur reminder berupa notifikasi yang akan dikirimkan ke email user yang telah terdaftar dalam sistem yang bertujuan untuk me-reminder tim eksekutor RAN untuk selalu menjalankan jobdesknya berupa membuat laporan hasil eksekusi data proyek dan mengunggahnya ke dalam sistem pelaporan hasil kerja.

\section{DAFTAR ISI}

[1] L. H. G. Kenneth Thompson, Papers on the Science of Administration, Illustrate. Psychology Press, 2003.

[2] I. Ooredoo, "Profil Perusahaan," 2017-01-01, 2017. [Online]. Available: https://indosatooredoo.com/id/about-indosat/corporate-profile. [Accessed: 11-Apr-2019].

[3] A. D. P. S. I. dengan C. dan LAVAREL, No Title, Cetakan Pe Yogyakarta: CV.LOKOMEDIA, 2018

[4] T. Subari, Konsep Sistem Informasi. Yogyakarta: Penerbit Andi, 2012

[5] H. Tohari, Analisa serta Perancangan Sistem Informasi Melalui Pendekatan UML. Yogyakarta: C.V ANDI OFFSET (Penerbit Andi), 2014

[6] Indrajani, Bedah Kilat 1 Jam Pengantar dan Sistem Basis Data. Jakarta: PT.Media Elex Media Komputindo, 2014

[7] R. Sahara and I. Ranggadara, "Design and Implementation of Treasury Application Based on Mobile in Student Organization Mercu Buana University," Ijcsmc, vol. 7, no. 2, pp. 1-8, 2018.

[8] K. Imtihan, R. Hadawiyah, and H. Asyari, "Sistem Informasi Penggajian Guru Honorer Menggunakan Konsep Agile Software Development dengan Metodologi Extreme Programming ( XP ) pada SMK Bangun Bangsa,"vol. 7, no. 2, 2017.

[9] M. Jamil and Bunyamin, "Pengembangan Aplikasi Sistem Informasi Laporan Keuangan Walisantri Di Pondok Pesantren Al-Halim Garut," J. Algoritm., vol. 12, pp. 1-6, 2015.

[10] D. A. Istyana and R. Sahara, "WEB-BASED APPLICATION FOR TRACKING , LISTING AND REPORTING DOCUMENT REVIEW ( CASE STUDY : PT . XYZ )," vol. 7, no. 11, pp. 84-91, 2018

[11] A. Utami, Feri Hari, Rekayasa Perangkat Lunak. Yogyakarta: Deepublish Publisher, 2015.

[12] L. J. Whitten, Metode Desain dan Analisis Sistem. Yogyakarta: Penerbit Andi, 2004

[13] Kosidin and R. N. Farizah, "Pemodelan Aplikasi Mobile Reminder Berbasis Android," Semin. Nas. Teknol. Inf. dan Komunikas 2016, vol. 2016, no. Sentika, pp. 271-280, 2016 